\title{
Article \\ Ultrasonic Properties of a Stone Architectural Heritage and Weathering Evaluations Based on Provenance Site
}

\author{
Young Hoon Jo (D) and Chan Hee Lee *(D)
}

check for updates

Citation: Jo, Y.H.; Lee, C.H.

Ultrasonic Properties of a Stone Architectural Heritage and Weathering Evaluations Based on Provenance Site. Appl. Sci. 2022, 12, 1498. https://doi.org/10.3390/ app12031498

Academic Editors: Daniela Di Martino, Maria Pia Riccardi and Massimiliano Clemenza

Received: 12 January 2022

Accepted: 28 January 2022

Published: 30 January 2022

Publisher's Note: MDPI stays neutral with regard to jurisdictional claims in published maps and institutional affiliations.

Copyright: (C) 2022 by the authors. Licensee MDPI, Basel, Switzerland. This article is an open access article distributed under the terms and conditions of the Creative Commons Attribution (CC BY) license (https:// creativecommons.org/licenses/by/ $4.0 /)$.

\author{
Department of Cultural Heritage Conservation Sciences, Kongju National University, Gongju 32588, Korea; \\ joyh@kongju.ac.kr \\ * Correspondence: chanlee@kongju.ac.kr; Tel.: +82-041-850-8543
}

\begin{abstract}
In this study, we performed customized ultrasonic measurements of the stone block foundation of the Sungnyemun Gate, which is representative of the stone architectural heritage in the Republic of Korea. Furthermore, the weathering evaluation standards, which are extensively used in stone heritage, were improved considering the type of rock and its provenance site. In particular, the absolute weathering grade used the ultrasonic velocity ( $\mathrm{P}$-wave) of a universal hard rock, whereas the relative weathering grade used the differences between the ultrasonic velocities of the materials in the stone block foundation of the Sungnyemun Gate (weathered stone) and the fresh rocks in the provenance. Among these, the absolute weathering grade was observed to be constant regardless of the type of rock; however, the relative weathering grade varied depending on the type dof rock. Because the average ultrasonic velocity of the original blocks of the stone block foundation of the Sungnyemun Gate was $2665 \mathrm{~m} / \mathrm{s}$, it was estimated that their ultrasonic velocity reduced by approximately $2.1 \mathrm{~m} / \mathrm{s}$ per year as compared to that observed in case of fresh rocks (average $3932 \mathrm{~m} / \mathrm{s}$ ) in the provenance site. Furthermore, the weathering evaluation exhibited that there were approximately two stages of difference between the original blocks and the new blocks. As compared to the relative weathering grade, the absolute weathering grade was observed to underestimate the overall ultrasonic velocity of the stone block foundation of the Sungnyemun Gate. This study presents a customized method for performing ultrasonic measurements and for evaluating weathering. It is assumed that the results of this study will be extensively used in diagnosing and monitoring the stone architectural heritage.
\end{abstract}

Keywords: ultrasonic measurement; weathering evaluation; relative and absolute weathering grades; stone architectural heritage; stone block foundation; Sungnyemun Gate

\section{Introduction}

The physical and structural deformation of stone architectural heritage is generally caused by natural weathering and short-term damage. Fortunately, the rocks are considerably durable because they have been able to endure several million years of geological activity; therefore, long-term weathering does not considerably impact the stability of a stone architectural heritage. However, structural defects, environmental changes, and intentional damage are important factors that cause the short-term damage of a stone architectural heritage. Therefore, evaluating and monitoring the durability of constituent rocks against weathering and damage are essential to maintain the stability of a stone architectural heritage that is exposed outdoors, thereby preserving its original form.

The most extensively known methods for evaluating the weathering of a stone architectural heritage include visual inspection and non-destructive testing. Although visual inspection based on a preliminary survey is very useful for precisely categorizing and mapping the defects, the scope of visual inspection is limited because it depends on the visual resolution and because it only detects the surface $[1,2]$. Further, non-destructive 
testing is advantageous to quantitatively determine the physical and structural defects that are observed from the surface to the inside of the structure.

Some common testing methods for stone architectural heritages include ultrasonic measurement [3-5], infrared thermographic analysis [4-9], ground-penetrating radar [10,11], rebound hardness measurement [12,13], and drilling resistivity testing [14,15] among various other methods. One of the most extensively used testing methods for detecting defects and for evaluating the weathering of a stone architectural heritage is ultrasonic measurement using the P-wave velocity, which is highly sensitive to cracks, schistosity, mineral composition, water content, and erosion [16,17].

However, ultrasonic measurements are influenced by various factors such as the petrological characteristics and shape of the stone heritage, the external environment, the measurement conditions, and the level of experience of the user. Thus, researchers have attempted to improve the reliability of these measurements by conducting experiments related to the moisture content [18-21] and anisotropy [22-24] of the rocks, the surface roughness [25], the direct and indirect correlation of ultrasonic waves [26-29], and the effects of the probe [30], couplant [25], and measuring operator [31].

Such studies have made a significant contribution to set the conditions for performing ultrasonic measurements. However, there are still several issues related to analysis and evaluation of weathering considering the material characteristics and the conservation conditions of a stone architectural heritage. This is because even a stone architectural heritage can include different types of stones; further, if a stone architectural heritage shows poor conservation condition, new stones may be used to replace the weathered stones during restoration. Furthermore, different types of rock exhibit different physical properties; even identical types of rock may exhibit different absolute strengths depending on its origin. Therefore, the weathering grade standards that consider the type of rock and the conservation condition of a target heritage should be established to evaluate the weathering of a stone architectural heritage based on ultrasonic measurements [32-37].

In this study, the conservation condition of the surface of the stone block foundation of the Sungnyemun Gate, one of the most representative stone buildings in the Republic of Korea, was primarily examined. The weathering of each block was quantitatively evaluated by performing ultrasonic measurements. First, a detailed visual inspection, a simple testing, and an analysis of contaminants were conducted to diagnose the conservation condition. Further, suitable customized conditions were established for performing the ultrasonic measurements of the stone block foundation of the Sungnyemun Gate, and the reliability of weathering evaluation was improved by considering the material characteristics and the provenance of the constituent stone materials. Because this study presents a customized model for performing ultrasonic measurements and for evaluating weathering, it is assumed that the results of these measurements will be extensively used in diagnosing and monitoring the stone architectural heritage.

\section{Research Object}

\subsection{Historical Implications}

The Sungnyemun Gate, which is the front gate of the Seoul City Wall (included in the temporary UNESCO World Heritage list), is one of the oldest fortress gates in the Republic of Korea. The structure has a stone block foundation that is built with rectangular stone materials with an arch in the center. On top, there is a gatehouse with five spaces at the front and two spaces at the side. Construction began in 1396 (year 5 of the reign of King Taejo) and was completed in 1398. Partial repair work was undertaken in 1448 (year 40 of the reign of King Sejong) and in 1479 (year 10 of the reign of King Seongjong).

For the subsequent 500 years or so, the original form of the gate was well maintained; however, in the early 1900s, the expansion of roads and the operation of streetcars led to the demolition of the left and right walls of the gate. During the Korean War in 1950, the stone block foundation and gatehouse were heavily damaged due to the fighting and a considerable part of the gate was destroyed. Between 1961 and 1963, major repair work 
was conducted during which the partial disassembly and restoration resulted in replacing some stone blocks with new ones (Figure 1a,b). Additionally, in February 2008, a fire broke out, which destroyed more than half of the gatehouse; however, fortunately, the stone block foundation was only slightly damaged (Figure 1c). The restoration work was completed in 2013 after five years of repair work. Since then, the gate has been maintained in a stable manner (Figure 1d).
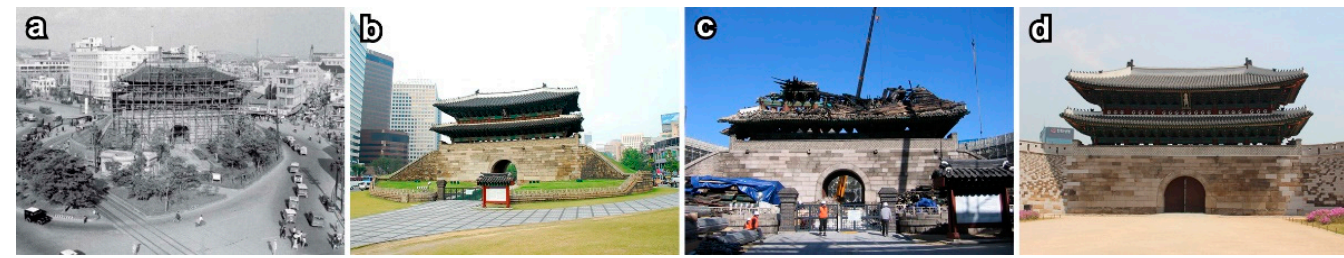

Figure 1. History of the stone block foundation (source: Korean Cultural Heritage Administration, 2018). (a) Repair work conducted in 1961-1963. (b) Appearance in 2007. (c) After a fire in 2008. (d) After completion of the restoration work in 2013.

\subsection{Material Characteristics}

The petrological properties of constituent stones in the stone block foundation of the Sungnyemun Gate have been detailed by Jo et al. [38], based on which we can summarize the material characteristics. Initially, the categorization of original and new blocks based on the repair work that was conducted after the Korean War exhibited that $60(20.7 \%)$ out of 290 blocks on the south face and $28(7.4 \%)$ out of 375 blocks on the north face were replaced with new blocks. Thus, the overall percentages of original and new blocks were observed to be approximately $86.8 \%$ and $13.2 \%$, respectively (Figure 2 ).

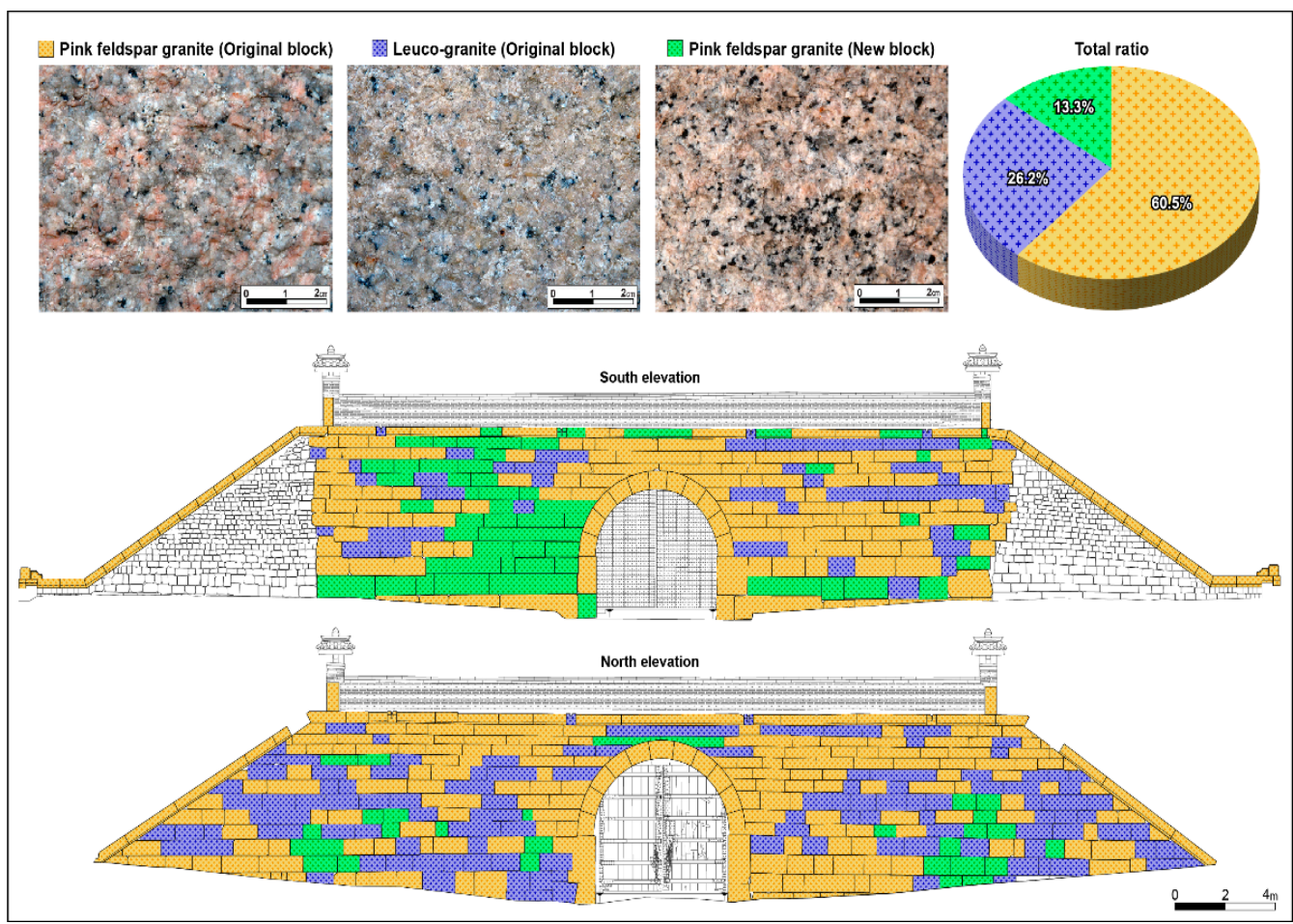

Figure 2. Map of the various rock types and their ratios in the stone block foundation (modified from Jo et al., 2012 [38]).

The constituent materials of the stone block foundation of the Sungnyemun Gate are medium-to coarse-grained granite. Based on the petrographic features using visible observation and polarizing microscopy, the original blocks comprise pink feldspar 
granite $(60.5 \%)$ and leucogranite $(26.2 \%)$, whereas the new blocks only comprise pink feldspar granite (Figure 2). By considering that these rocks are almost identical with each other in terms of their mineralogical and geochemical characteristics even though they differ in terms of color and magnetic susceptibility, we infer that all of these rocks originate from magma of the same type. An analysis of the provenance of the stone materials that were located around the Seoul City Wall showed that both the pink feldspar granite and the leucogranite originated from within $4 \mathrm{~km}$ of the Sungnyemun Gate [38].

\section{Conservation Status}

\subsection{Physical Deterioration}

The stone block foundation of the Sungnyemun Gate exhibits physical damage, mainly cracks, blistering, scaling, granular disintegration, fragmentation, and bullet traces by a gunfight. As depicted in the physical deterioration map in Figure 3, the frequency of cracks on the north face was approximately three times that observed on the south face. The cracks are concentrated in the original blocks and can be divided into hair, blistering, and structural cracks. Further, the crack index proposed by Jo and Lee [39] was calculated. The hair crack index was 0.16 on the south face and 1.09 on the north face, the blistering crack index was 1.76 on the south face and 3.06 on the north face, and the structural crack index was 0.15 on the south face and 0.75 on the north face. The blistering cracks showed the most damage. There was less crack damage on the south face, where a higher number of original blocks was replaced with new blocks as compared to the north face.

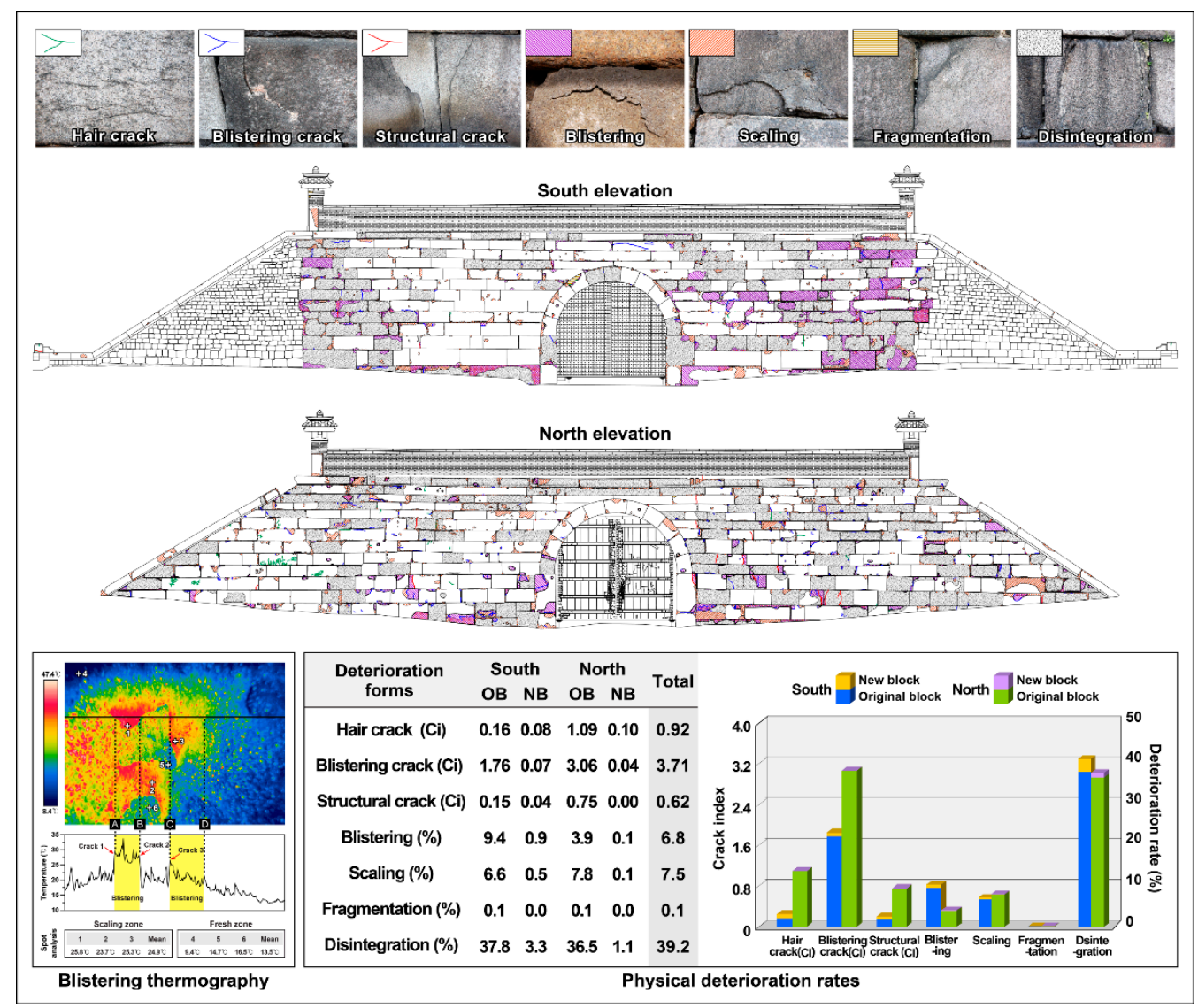

Figure 3. The physical deterioration maps and quantitative evaluation of the stone block foundation.

The deterioration of the stone block foundation due to blistering was examined by tapping testing and quantification modeling [40] based on a thermographic analysis. The blistering on the south face was $9.4 \%$ on the original blocks and $0.9 \%$ on the new blocks, whereas the blistering on the north face was $3.9 \%$ on the original blocks and $0.1 \%$ on the 
new blocks. It can be assumed that the reason for the relatively higher blistering damage on the south face as compared to that observed on the north face was the gun battle that occurred near the south face in 1950 during the Korean War, which may have caused blistering (Figure 3).

Additionally, scaling was $7.1 \%(6.6 \%$ on the original blocks and $0.5 \%$ on the new blocks) on the south face and $7.9 \%$ (7.8\% on the original blocks and $0.1 \%$ on the new blocks) on the north face. Fragmentation was only visible on the arch of the south face. Disintegration was $41.1 \%$ on the south face $(37.8 \%$ on the original blocks and $3.3 \%$ on the new blocks) and $37.6 \%$ on the north face (36.5\% on the original blocks and $1.1 \%$ on the new blocks). Even though the disintegration is similar for each face, it is concentrated in the original blocks.

\subsection{Surface Contamination and Discoloration}

Because of the complex interaction of discoloration that is caused by natural chemical weathering and contaminants in the air, it is difficult to verify the color and texture of the original rock that is used in the stone block foundation of the Sungnyemun Gate. A majority of the surface contamination and discoloration has resulted in a brownish color because of the weathering of ferruginous minerals, dark brown rust from the iron plates between the blocks, black crusts due to exhaust gases from automobiles, efflorescence caused by the materials used for repairs, and microorganisms that exist in some places (Figure 4). Therefore, a scanning electron microscopy/energy dispersive X-ray spectroscopy (SEM/EDS) analysis was conducted on micro-specimens to determine the causes and mechanism of various contaminants (Table 1).
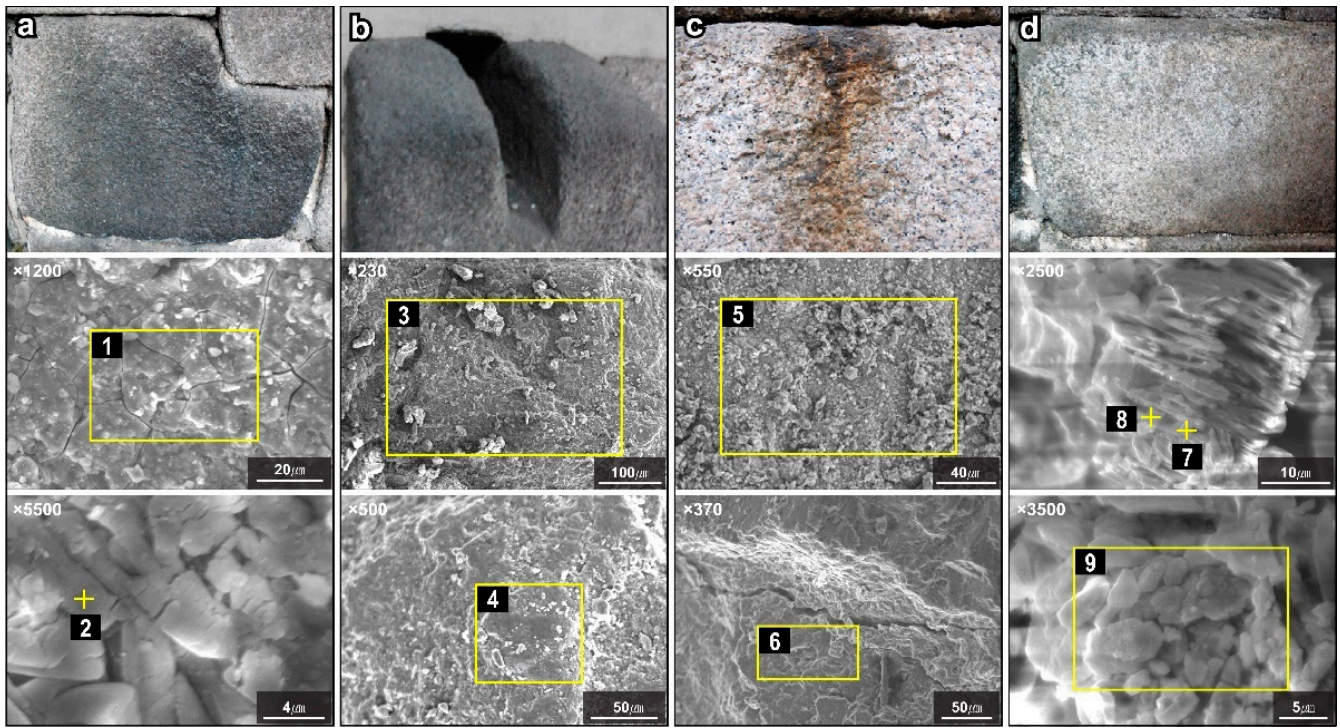

Figure 4. Photographs and scanning electron microscopic images of the surface contaminants of stone block foundation. (a) Black crusts. (b) Brown discoloration from iron plates. (c) Salt weathering. (d) Green discoloration from microorganisms.

The black crusts comprise carbon materials (13.0 wt.\%), which exhibit craquelures that completely cover the original rock as well as gypsum crystals (25.9 wt.\% calcium and $22.3 \mathrm{wt}$ \% sulfur) (Figure 4a). The discoloration due to rust from the iron plates is a combination of amorphous iron oxide (33.6-37.9 wt.\%), carbon (2.9-16.7 wt.\%), and a clay mineral (Figure $4 \mathrm{~b})$. The efflorescence contaminants include gypsum crystals (20.2-39.8 wt.\% calcium and 17.4-26.8 wt.\% sulfur). The crystals are scattered in clusters on the surface, most of which are observed to grow between the cleavage planes of biotite (Figure 4c). 
Table 1. Results of SEM-EDS analysis for surface contaminants (wt.\%). The analysis spots are similar to those in Figure 4.

\begin{tabular}{ccccccccccccc}
\hline Spots & $\mathbf{S i}$ & $\mathbf{A l}$ & $\mathbf{F e}$ & $\mathbf{C a}$ & $\mathbf{M g}$ & $\mathbf{N a}$ & $\mathbf{K}$ & $\mathbf{P}$ & $\mathbf{S}$ & $\mathbf{C l}$ & $\mathbf{C}$ & $\mathbf{O}$ \\
\hline 1 & 14.8 & 8.8 & - & - & - & - & - & - & 4.2 & - & 13.0 & 59.2 \\
2 & - & - & - & 25.9 & - & - & - & - & 22.3 & - & 2.8 & 49.0 \\
3 & 6.8 & 3.8 & 33.6 & - & - & - & 0.6 & - & - & - & 16.7 & 38.6 \\
4 & 11.6 & 5.0 & 37.9 & 2.0 & - & - & 1.0 & 2.8 & 1.9 & 1.1 & 2.9 & 33.7 \\
5 & 7.1 & 2.4 & - & 20.2 & 1.0 & 2.3 & 1.3 & - & 17.4 & 0.9 & 0.5 & 46.9 \\
6 & 3.3 & 1.3 & - & 39.8 & - & - & 1.1 & - & 26.8 & - & 4.3 & 23.4 \\
7 & 5.8 & - & - & 28.9 & - & - & - & - & 19.1 & - & - & 46.2 \\
\hline
\end{tabular}

It is assumed that the stone block foundation of the Sungnyemun Gate has undergone chemical weathering, primarily due to the oxidation of ferruginous minerals and moisture but also because of secondary contaminants, such as air pollutants, salt crystals, clay minerals, and microorganisms, all of which are consistently adhered onto the surface and promote discoloration (Figure 4d). Such organic and inorganic contaminants not only damage the beauty of the heritage but can also cause physical damage, such as blistering, scaling, and disintegration, by increasing the surface pressure. Therefore, an urgent conservation treatment is required.

\section{Methodology for Weathering Evaluation}

The evaluation of the weathering of the rock by measuring its ultrasonic velocity has been performed for a long time. Because this evaluation is a highly reliable method of non-destructive testing, several countries use it as the geological standard. Many researchers quantitatively categorize weathering grades into three to five stages according to various types of rocks, such as natural stone [41], acidic volcanic rock [37], limestone [42], andesite [36], marble [43], and granite [44] (Table 2). Among these, the durability of the natural stone does not only depend on the alteration factors, and it also depends on the mineralogy, the rock fabric, and the pore system [45]. To determine the weathering status of a stone architectural heritage based on ultrasonic velocity, we can use the already reported standards.

Table 2. The weathering classifications based on ultrasonic velocity $(\mathrm{m} / \mathrm{s})$.

\begin{tabular}{|c|c|c|c|c|c|c|}
\hline \multirow{2}{*}{ References } & \multirow{2}{*}{ Rock Types } & \multicolumn{5}{|c|}{ Weathering Classification } \\
\hline & & I (FR) & II (SW) & III (MW) & IV (HW) & $\mathrm{V}(\mathrm{CW})$ \\
\hline Matula et al. (1979) [41] & Natural stones & $>5000$ & $4000 \sim 5000$ & $3500 \sim 4000$ & $2500 \sim 3500$ & $<2500$ \\
\hline Arikan et al. (2007) [34] & $\begin{array}{c}\text { Acidic volcanic } \\
\text { rock }\end{array}$ & $>3862$ & $3242 \sim 3861$ & $2623 \sim 3242$ & $<2623$ & - \\
\hline Fitzner and Heinrichs (1990) [42] & Limestone & $3900 \sim 4100$ & $3000 \sim 3900$ & $2000 \sim 3000$ & $1000 \sim 2000$ & $<1000$ \\
\hline Iliev (1966) [32] & Monzonite & $>5000$ & $4000 \sim 5000$ & $3000 \sim 4000$ & $2000 \sim 3000$ & $<2000$ \\
\hline Karpuz and Paşamehnetoğlu (1997) [33] & Andesite & $>3900$ & $3050 \sim 3900$ & $2250 \sim 3050$ & $1350 \sim 2250$ & $<1350$ \\
\hline Köhler (1991) [43] & Marble & $>5000$ & $3000 \sim 5000$ & $2000 \sim 3000$ & $1500 \sim 2000$ & $<1500$ \\
\hline Lee and Cho (2005) [44] & Granite & $4220 \sim 5100$ & $2480 \sim 4120$ & $1450 \sim 2400$ & - & - \\
\hline
\end{tabular}

However, Iliev [35] reported that the physical and structural changes of a weathered stone could be analyzed by comparing its ultrasonic velocity with that of a fresh rock, based on which $K$, the weathering coefficient, can be determined as follows:

$$
K=\frac{V_{f}-V_{w}}{V_{f}}
$$

where $V_{f}$ and $V_{w}$ are the P-wave velocities of a fresh and weathered rock, respectively. As the stone weathers, $K$ increases uniformly. Further, $K$ encompasses the overall effect of various factors, such as the density, porosity, and expansion of micro-cracks, which are 
highly sensitive to weathering. It is a relatively simple and highly applicable measure of weathering [46,47].

Thus, applying the already reported standards or calculating the weathering coefficient, $K$, is required to evaluate the weathering of a stone architectural heritage using ultrasonic measurements. Among these, the weathering coefficient $K$, based on the rates of ultrasonic velocity, changes between fresh and weathered rocks; it can be customized by considering the rock type of a stone architectural heritage [48]. In case of the weathering coefficient, once the ultrasonic velocity of fresh rock in the provenance of a stone architectural heritage is determined, the relative weathering after construction can be determined. Additionally, the coefficient can compare the absolute strength between rocks regardless of the rock type using the ultrasonic velocity of a universal hard rock $(5000 \mathrm{~m} / \mathrm{s})$ without considering that of a fresh rock in the provenance. Therefore, this study classified the weathering coefficient $K$ as the relative and absolute weathering grades according to the standard ultrasonic velocities of the fresh rocks. These grades were applied to the analysis of the stone block foundation of the Sungnyemun Gate.

To determine the relative weathering of the stone block foundation of the Sungnyemun Gate, the ultrasonic velocities of fresh pink feldspar granite and leucogranite were measured at the provenance site (quarry). The site is reported as the Namsan mountain in Seoul, Republic of Korea by Jo et al. [38] and Jo and Lee [49]. The ultrasonic measurements of the rocks at the provenance were conducted using same methods and procedures as those used for analyzing the stone block foundation. The average ultrasonic velocity of fresh pink feldspar granite was $3829 \mathrm{~m} / \mathrm{s}$ (3659-4000 m/s), and that of fresh leucogranite was $4036 \mathrm{~m} / \mathrm{s}(3911-4286 \mathrm{~m} / \mathrm{s})$, indicating that the overall physical properties of leucogranite were somewhat high (Table 3). These ultrasonic velocities were used as fresh standards for evaluating the relative weathering of the two types of rock that constituted the stone block foundation of the Sungnyemun Gate.

Table 3. The mean, minimum, and maximum ultrasonic velocities $(\mathrm{m} / \mathrm{s})$ and standard deviations of fresh rocks in the provenance site.

\begin{tabular}{ccccc}
\hline Rock Types & Mean & Min. & Max. & SD \\
\hline Pink feldspar granite & 3829 & 3659 & 4000 & 91 \\
Leucogranite & 4036 & 3911 & 4286 & 115 \\
Total & 3932 & 3659 & 4286 & 147 \\
\hline
\end{tabular}

The rocks that constitute the stone architectural heritage include granite, gneiss, marble, and sandstone. At the time of this study, these rocks exhibit different physical properties and strengths from those at the time of their creation. Therefore, the ultrasonic velocity of a universal hard rock needs to be determined to compare the absolute strengths observed in various types of rocks. In this study, a database was established by analyzing a Republic of Korean and foreign research that provided the ultrasonic velocity of fresh rock (Table 4). Each rock type exhibited a different ultrasonic velocity; even rocks of the same type can possess different ultrasonic velocities based on the corresponding provenance sites.

The granites in the database exhibit ultrasonic velocities that are similar to those observed at the provenance site of the stone block foundation of the Sungnyemun Gate. In this study, the absolute weathering used a $5000 \mathrm{~m} / \mathrm{s}$ ultrasonic velocity [32], which was extensively used as the standard for fresh rock, among the various ultrasonic velocities observed based on the type of rock. Table 5 presents the relative weathering grade using the ultrasonic velocity of fresh rock in the provenance site of the stone block foundation of the Sungnyemun Gate and absolute weathering grade based on a $5000 \mathrm{~m} / \mathrm{s}$ velocity. Although the relative weathering grade differs with the type of rock, the absolute weathering grade is standard regardless of the type of rock. 
Table 4. The P-wave velocities of fresh rocks.

\begin{tabular}{|c|c|c|}
\hline Rock Types & Location & Velocity $(\mathrm{m} / \mathrm{s})$ \\
\hline \multirow{14}{*}{ Granite } & Geochang in Korea [44] & 3946 \\
\hline & Geochang in Korea [44] & 3877 \\
\hline & Geochang in Korea [44] & 3680 \\
\hline & Iksan in Korea [44] & 3360 \\
\hline & Yangju in Korea [44] & 4062 \\
\hline & Gimcheon in Korea [44] & 4980 \\
\hline & Geumsan in Korea [50] & 5200 \\
\hline & Jecheon in Korea [50] & 3901 \\
\hline & Jecheon in Korea [51] & 3650 \\
\hline & Ganghwa in Korea [51] & 4600 \\
\hline & Yeosu in Korea [51] & 3470 \\
\hline & Hwangdeung in Korea [51] & 3230 \\
\hline & Malanjkhand in India [52] & 5983 \\
\hline & Mean & 4149 \\
\hline Granodiorite & Gimcheon in Korea [50] & 4500 \\
\hline Monzonite & - & 5000 \\
\hline \multirow{4}{*}{ Diorite } & Gongju in Korea [44] & 4594 \\
\hline & Gongju in Korea [44] & 4724 \\
\hline & Chungju in Korea [44] & 3826 \\
\hline & Mean & 4381 \\
\hline Gabbro & Macheon in Korea [51] & 3370 \\
\hline Basalt & Delhi in India [51] & 5760 \\
\hline Granite gneiss & Gimcheon in Korea [50] & 4290 \\
\hline Gneiss & Massiac in France [53] & 5000 \\
\hline Quartzite & Nagpur in India [50] & 5800 \\
\hline \multirow{4}{*}{ Marble } & Wanju in Korea [44] & 4866 \\
\hline & Jeongseon in Korea [51] & 4620 \\
\hline & Isparta in Turkey [54] & 4309 \\
\hline & Mean & 4598 \\
\hline Limestone & Isparta in Turkey [54] & 6355 \\
\hline Travertine & Isparta in Turkey [54] & 4309 \\
\hline \multirow{3}{*}{ Sandstone } & Boryeong in Korea [44] & 5101 \\
\hline & Sangju in Korea [51] & 3770 \\
\hline & Mean & 4436 \\
\hline
\end{tabular}

Table 5. The P-wave velocity $(\mathrm{m} / \mathrm{s})$ ranges of relative and absolute grades of the stone block foundation based on the weathering coefficient, $K$ [32].

\begin{tabular}{|c|c|c|c|c|}
\hline \multirow{2}{*}{\multicolumn{2}{|c|}{ Weathering Coefficient $K$}} & \multicolumn{2}{|c|}{ Relative Weathering Grade } & \multirow{3}{*}{$\begin{array}{c}\text { Absolute Weathering Grade } \\
\qquad 5000\end{array}$} \\
\hline & & \multirow{2}{*}{$\begin{array}{c}\text { Pink Feldspar Granite } \\
\geq 3829\end{array}$} & \multirow{2}{*}{$\begin{array}{c}\text { Leucogranite } \\
\geq 4036\end{array}$} & \\
\hline I & $\mathrm{FR} \leq 0$ & & & \\
\hline II & $0<\mathrm{SW} \leq 0.2$ & $3063 \leq \mathrm{SW}<3829$ & $3229 \leq \mathrm{SW}<4036$ & $4000 \leq \mathrm{SW}<5000$ \\
\hline III & $0.2<\mathrm{MW} \leq 0.4$ & $2297 \leq \mathrm{MW}<3063$ & $2422 \leq \mathrm{MW}<3229$ & $3000 \leq \mathrm{MW}<4000$ \\
\hline IV & $0.4<\mathrm{HW} \leq 0.6$ & $1532 \leq \mathrm{MW}<2297$ & $1614 \leq \mathrm{MW}<2422$ & $2000 \leq \mathrm{MW}<3000$ \\
\hline $\mathrm{V}$ & $0.6<\mathrm{CW} \leq 1.0$ & $<1532$ & $<1614$ & $<2000$ \\
\hline
\end{tabular}

\section{Result and Interpretation}

\subsection{Ultrasonic Measurement Conditions}

The equipment used for the ultrasonic measurement of the stone block foundation of the Sungnyemun Gate was a Pundit-plus instrument by CNS Farnell (Borehamwood, UK), which is extensively used in Republic of Korea and various other countries in rock en- 
gineering and for a stone architectural heritage. The ultrasonic pulse voltage was set to $1200 \mathrm{~V}$. The stone block foundation of the Sungnyemun Gate has surface irregularities that impact transducer and decrease the repeatability and reliability of measurements. There, the exponential transducer (a nominal 54-kHz frequency) with a 6-mm contact area and dried rubber clay couplant, which does not leave a residue, was used for the measurements. This setup is suitable for performing ultrasonic measurements of rough surfaces, such as that of a stone architectural heritage [25,55].

Water increases the ultrasonic velocity when it fills pores and microcracks of rocks [56]. Accordingly, the on-site ultrasonic measurements were considered drying conditions of the stone block foundation that are unaffected by the rain. The path length between the transmitter and receiver was set to $200 \mathrm{~mm}$ using the indirect method. The areas of contaminants and rough surfaces that may reduce the ultrasonic were avoided; thus, ultrasonic velocities were acquired from 790 and 1067 points on the south and north faces, respectively. The resulting indirect ultrasonic velocity was converted to a direct ultrasonic velocity using the mean correction factor for medium-to-coarse granite, 1.50, as proposed by Lee and Jo [29].

\subsection{Distribution of Ultrasonic Velocity}

For the original blocks, the average ultrasonic velocities and ranges on the south and north faces were similar at $2783 \mathrm{~m} / \mathrm{s}(1235-4644 \mathrm{~m} / \mathrm{s})$ and $2591 \mathrm{~m} / \mathrm{s}(1351-4471 \mathrm{~m} / \mathrm{s})$, respectively (Figure 5, Table 6). The overall average ultrasonic velocity was $2665 \mathrm{~m} / \mathrm{s}$. Further, for the new blocks that were used as replacement stones after the Korean War, the average ultrasonic velocities and ranges on the south and north faces were almost identical at $3892 \mathrm{~m} / \mathrm{s}(2360-4732 \mathrm{~m} / \mathrm{s})$ and $3869 \mathrm{~m} / \mathrm{s}(2564-4762 \mathrm{~m} / \mathrm{s})$, respectively. The overall average ultrasonic velocity was $3884 \mathrm{~m} / \mathrm{s}$. Thus, the difference between the average ultrasonic velocities of the original and new blocks was $1219 \mathrm{~m} / \mathrm{s}$ (Figure 5, Table 6).

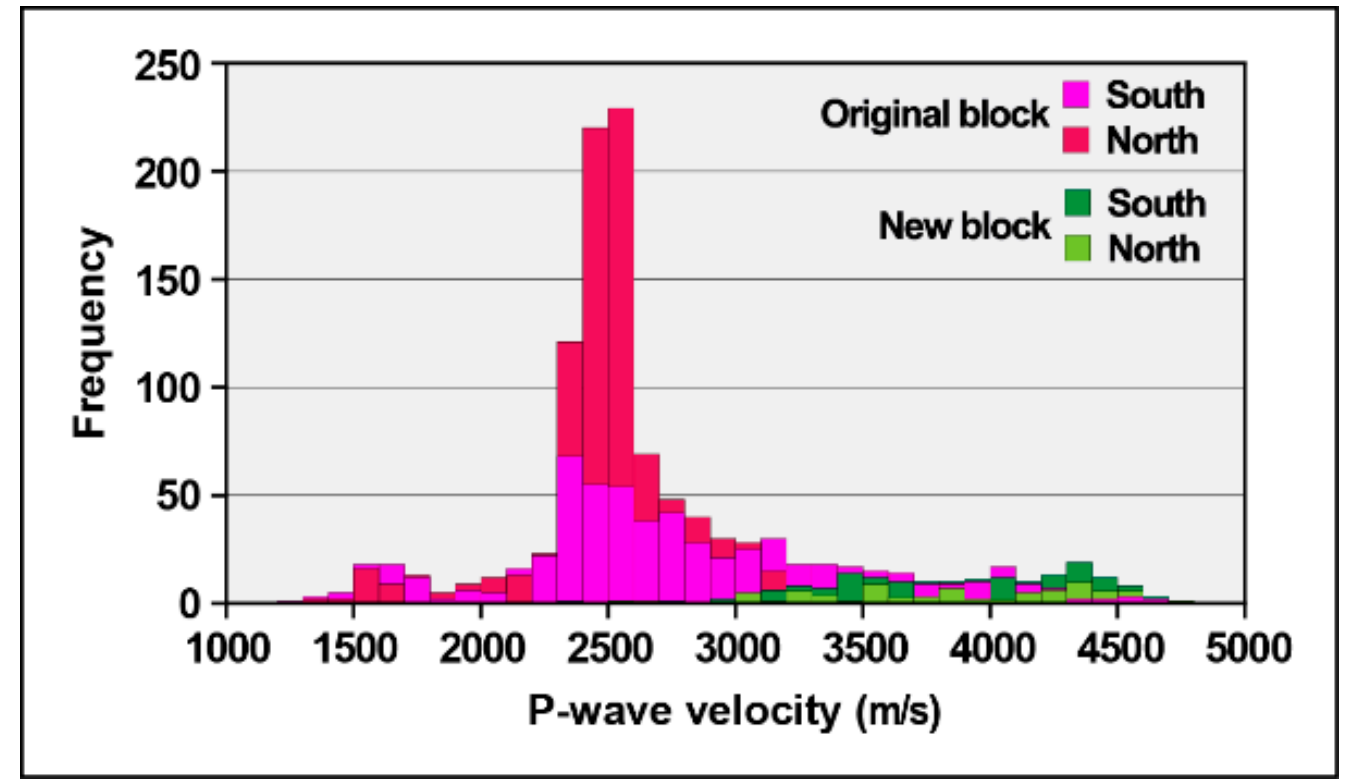

Figure 5. Histogram of the ultrasonic velocities of the stone block foundation.

The ultrasonic velocities were projected onto the south and north elevations to examine the overall weathering trend (Figure 6). As a result, the constituent stone materials of the stone block foundation manifested different physical properties based on the original and new blocks. In particular, some blocks on the south and north faces exhibited an extremely low ultrasonic velocity of lower than $1000 \mathrm{~m} / \mathrm{s}$; the low ultrasonic velocity zone was concentrated on the lowest part of the south face. 
Table 6. The mean, minimum, and maximum ultrasonic velocities $(\mathrm{m} / \mathrm{s})$ and standard deviations of the original and new blocks.

\begin{tabular}{|c|c|c|c|c|c|c|}
\hline Elevation & & Type & Mean & Min. & Max. & SD \\
\hline \multirow{4}{*}{ South } & \multirow{3}{*}{ Original block } & Pink feldspar granite & 2859 & 1235 & 4644 & 717 \\
\hline & & Leucogranite & 2571 & 1402 & 3704 & 492 \\
\hline & & Total & 2783 & 1235 & 4644 & 677 \\
\hline & New block & Pink feldspar granite & 3892 & 2360 & 4732 & 473 \\
\hline \multirow{4}{*}{ North } & \multirow{3}{*}{ Original block } & Pink feldspar granite & 2601 & 1431 & 4360 & 441 \\
\hline & & Leucogranite & 2577 & 1351 & 4471 & 401 \\
\hline & & Total & 2591 & 1351 & 4471 & 426 \\
\hline & New block & Pink feldspar granite & 3869 & 2564 & 4762 & 520 \\
\hline \multirow{4}{*}{ Overallelevation } & \multirow{3}{*}{ Original block } & Pink feldspar granite & 2713 & 1235 & 4644 & 591 \\
\hline & & Leucogranite & 2575 & 1351 & 4471 & 430 \\
\hline & & Total & 2665 & 1235 & 4644 & 545 \\
\hline & New block & Pink feldspar granite & 3884 & 2360 & 4762 & 488 \\
\hline
\end{tabular}

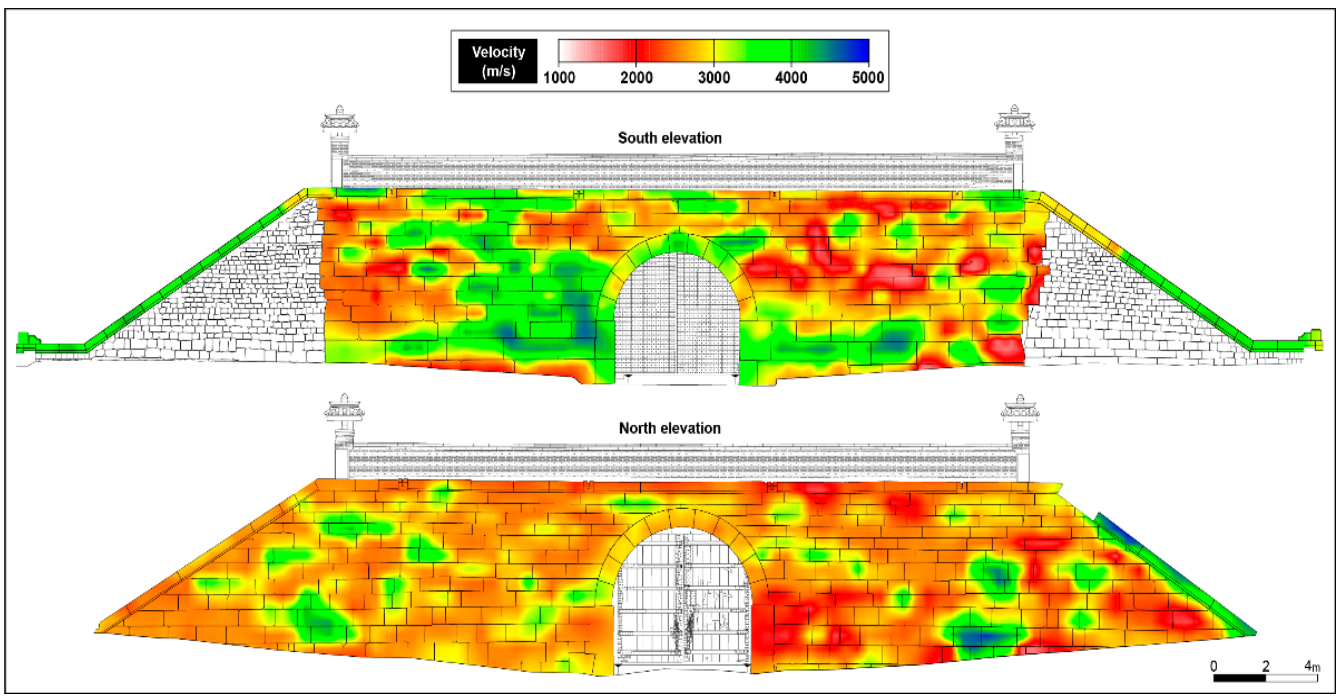

Figure 6. Contour maps of the ultrasonic velocities of the stone block foundation.

\subsection{Classification of the Weathering Grade}

The relative weathering coefficient of the stone materials for each face were calculated based on the ultrasonic velocity of the fresh pink feldspar granite and leucogranite at the provenance site of the stone block foundation of the Sungnyemun Gate (Figure 7). The weathering of the new and original blocks in both the south and north faces is clearly different. Overall, the south face, which has more new blocks than the north face, exhibits diverse weathering characteristics, from the fresh stage to the completely weathered stage.

A quantitative comparison was conducted between the relative and absolute coefficients of the stone block foundation of the Sungnyemun Gate by combining the weathering coefficients, K, of each point of the ultrasonic measurement by each block. The relative weathering grade of the original blocks based on the ultrasonic velocity of the fresh rock at the provenance site exhibits a normal distribution that is centered on the moderately weathered stage (63.6\%); however, the stages are observed to be mainly from the fresh (55.2\%) to the slightly weathered stage (41.4\%) for the new block (Figure 8a, Table 7). 


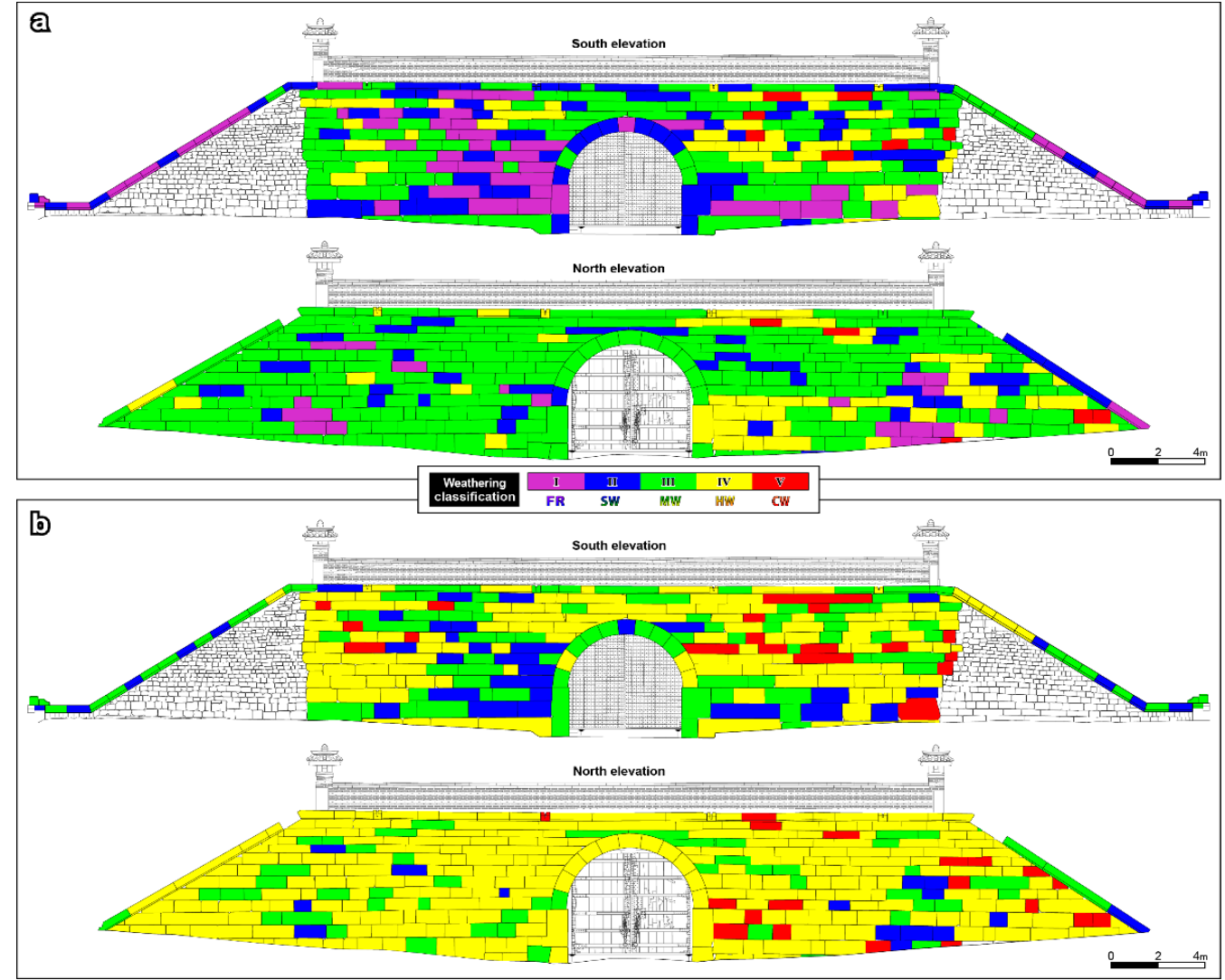

Figure 7. Block maps of weathering coefficient, $K$, in case of the stone block foundation. (a) Relative weathering grade. (b) Absolute weathering grade.

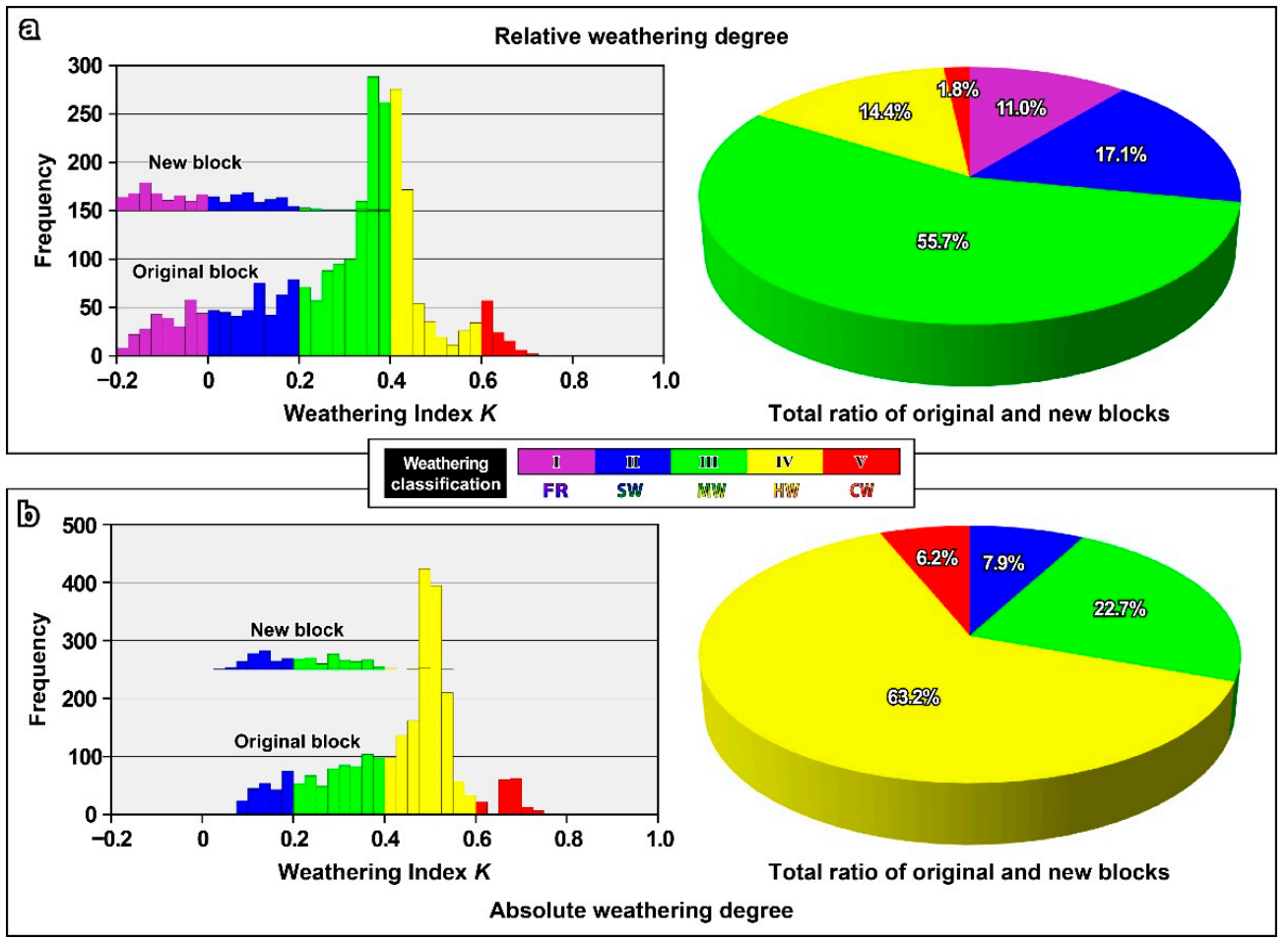

Figure 8. Histograms and pie diagrams of weathering classification in original and new blocks. (a) Relative weathering degree. (b) Absolute weathering degree. 
Table 7. Ratios (\%) of the relative and absolute weathering grades of the stone block foundation.

\begin{tabular}{|c|c|c|c|c|c|c|c|}
\hline \multirow{2}{*}{\multicolumn{2}{|c|}{ Weathering Classification }} & \multicolumn{3}{|c|}{ Relative Weathering Degree } & \multicolumn{3}{|c|}{ Absolute Weathering Degree } \\
\hline & & South & North & Total & South & North & Total \\
\hline \multirow{5}{*}{$\begin{array}{c}\text { Original } \\
\text { block }\end{array}$} & $\mathrm{FR} \leq 0$ & 9.6 & 0.9 & 4.4 & 0.0 & 0.0 & 0.0 \\
\hline & $0<\mathrm{SW} \leq 0.2$ & 21.0 & 8.4 & 13.4 & 5.7 & 0.6 & 2.6 \\
\hline & $0.2<\mathrm{MW} \leq 0.4$ & 48.0 & 73.9 & 63.6 & 29.3 & 10.4 & 17.9 \\
\hline & $0.4<\mathrm{HW} \leq 0.6$ & 18.3 & 15.4 & 16.6 & 55.5 & 83.5 & 72.3 \\
\hline & $0.6<\mathrm{CW} \leq 1.0$ & 3.1 & 1.4 & 2.1 & 9.6 & 5.5 & 7.1 \\
\hline \multirow{5}{*}{$\begin{array}{l}\text { New } \\
\text { block }\end{array}$} & $\mathrm{FR} \leq 0$ & 52.5 & 60.7 & 55.2 & 0.0 & 0.0 & 0.0 \\
\hline & $0<\mathrm{SW} \leq 0.2$ & 44.1 & 35.7 & 41.4 & 40.7 & 46.4 & 42.5 \\
\hline & $0.2<\mathrm{MW} \leq 0.4$ & 3.4 & 3.6 & 3.4 & 55.9 & 50.0 & 54.0 \\
\hline & $0.4<\mathrm{HW} \leq 0.6$ & 0.0 & 0.0 & 0.0 & 3.4 & 3.6 & 3.4 \\
\hline & $0.6<\mathrm{CW} \leq 1.0$ & 0.0 & 0.0 & 0.0 & 0.0 & 0.0 & 0.0 \\
\hline \multirow{5}{*}{ Total } & $\mathrm{FR} \leq 0$ & 18.4 & 5.4 & 11.0 & 0.0 & 0.0 & 0.0 \\
\hline & $0<\mathrm{SW} \leq 0.2$ & 25.7 & 10.5 & 17.1 & 12.8 & 4.0 & 7.9 \\
\hline & $0.2<\mathrm{MW} \leq 0.4$ & 38.9 & 68.6 & 55.7 & 34.7 & 13.4 & 22.7 \\
\hline & $0.4<\mathrm{HW} \leq 0.6$ & 14.6 & 14.2 & 14.4 & 44.8 & 77.5 & 63.2 \\
\hline & $0.6<\mathrm{CW} \leq 1.0$ & 2.4 & 1.3 & 1.8 & 7.6 & 5.1 & 6.2 \\
\hline
\end{tabular}

Furthermore, from the absolute weathering grade based on the ultrasonic velocity $(5000 \mathrm{~m} / \mathrm{s})$ of a universal hard rock, majority of the original blocks were observed to be at the highly weathered stage $(72.3 \%)$, while approximately $7.1 \%$ of the blocks were at the completely weathered stage. However, the new blocks were almost evenly split between the moderately $(54.0 \%$ ) and slightly $(42.5 \%)$ weathered stages (Figure $8 \mathrm{~b}$, Table 7 ). To summarize, the original and new blocks of the stone block foundation of the Sungnyemun Gate differed by approximately two weathering stages. The absolute weathering grade tends to underestimate the overall physical properties and strength of the blocks compared with the relative weathering grade.

\section{Discussion}

To use ultrasonic technology for the non-destructive testing of a stone architectural heritage, sufficiently reliable data must be acquired and a customized evaluation of the integrity must be conducted by considering the actual conservation condition of the target heritage. Therefore, in this study, ultrasonic measurement conditions that were suitable for a stone architectural heritage were established based on previous studies (Figure 9). To achieve this objective, a 54-kHz exponential transducer and rubber clay couplant were used. The ultrasonic velocity acquired at a $200 \mathrm{~mm}$ distance using the indirect transmission method was converted to a direct ultrasonic velocity using the average correction factor for medium-to-coarse granite of 1.50, as proposed by Lee and Jo [29].

The existing evaluation method, which is extensively used, can be improved by proposing weathering standards based on the material characteristics and provenance site of the constituent stone materials of the stone block foundation of the Sungnyemun Gate. In particular, the absolute weathering grade based on the ultrasonic velocity of universal hard rock and the relative weathering grade based on the ultrasonic velocity of fresh rock at the provenance site were suggested.

The standard ultrasonic velocity of the absolute weathering grade was set to $5000 \mathrm{~m} / \mathrm{s}$, which corresponded to that of fresh rock, as proposed by studies such as those by Matula et al. [41], Iliev [32], and Köhler [43]. The standard ultrasonic velocity of the relative weathering grade was measured from the provenance site of the constituent stone materials for the stone block foundation of the Sungnyemun Gate, based on which the weathering standards for fresh pink feldspar granite $(3829 \mathrm{~m} / \mathrm{s})$ and leucogranite $(4036 \mathrm{~m} / \mathrm{s})$ were established. The difference in weathering between the original and new blocks exhibited that the absolute weathering grade underestimated the overall physical properties and strength compared with the relative weathering grade. 


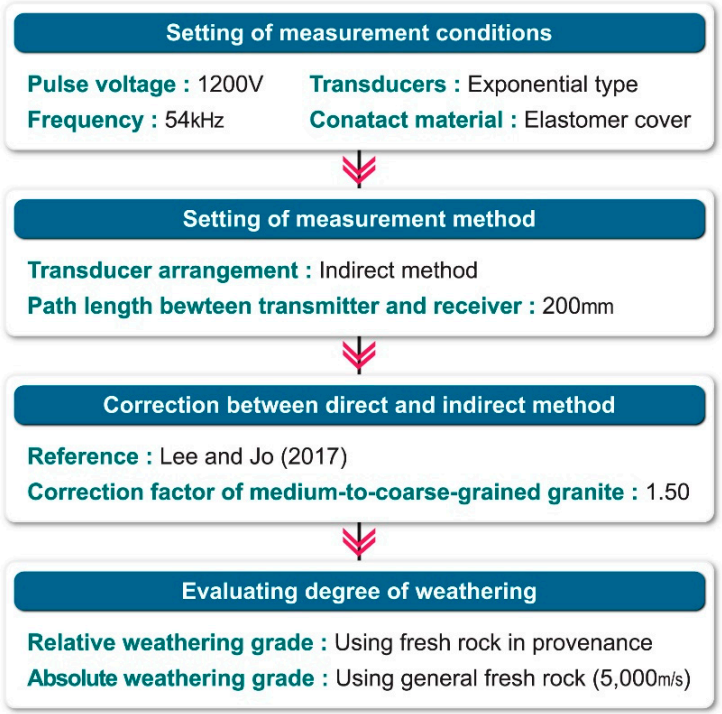

Figure 9. Process model of the ultrasonic measurements and weathering evaluation of the stone block foundation.

In particular, the ultrasonic velocity of fresh rock that was acquired from the provenance site was used as a standard for determining not only the weathering degree of the stone block foundation of the Sungnyemun Gate but also for the weathering trend. Because stone structures are originally built using fresh rocks, it can be assumed that the ultrasonic velocity of fresh rocks is the ultrasonic velocity of the stone block foundation of the Sungnyemun Gate when it was completed in 1398. Thus, at the time of the survey, the average ultrasonic velocities of the pink feldspar granite $(2713 \mathrm{~m} / \mathrm{s})$ and leucogranite $(2575 \mathrm{~m} / \mathrm{s})$ of the original blocks were observed to be a result of weathering for approximately 600 years.

The annual change in ultrasonic velocity was calculated as a linear function by dividing the difference between the ultrasonic velocities of fresh and weathered rocks by the weathering time. The result exhibited that the ultrasonic velocities of pink feldspar granite and leucogranite decreased annually by approximately 1.8 and $2.4 \mathrm{~m} / \mathrm{s}$, respectively (Figure 10). Thus, the annual change in the ultrasonic velocity of leucogranite is higher. By considering that intentional damage was caused to the original blocks in 1950 during the Korean War, this change in velocity was not attributed only to natural weathering. If this result is compared with that for stone structures without intentional damage, a relative comparison of weathering characteristics may be possible.

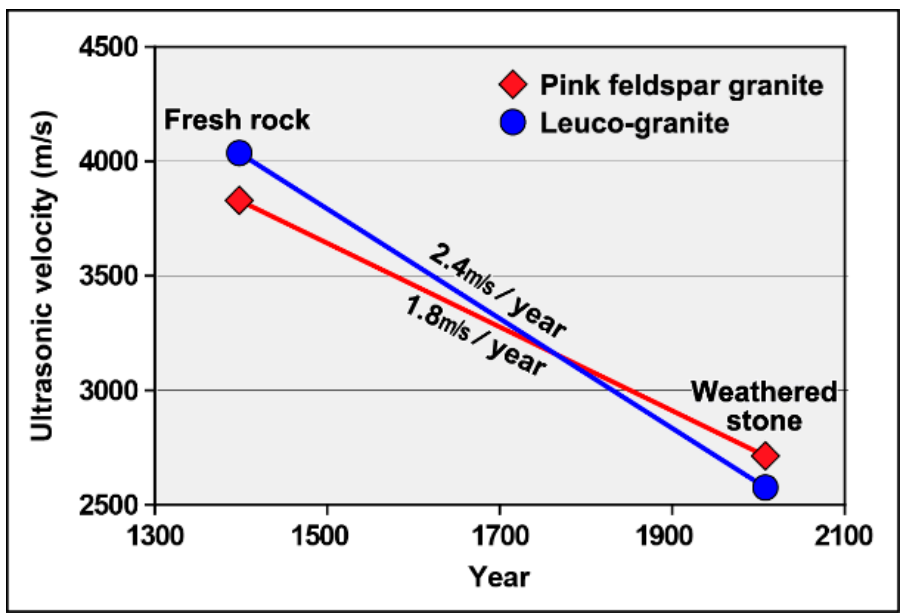

Figure 10. The weathering characteristics of original blocks after construction of the stone block foundation in 1398. 


\title{
7. Conclusions
}

In this study, customized conditions for ultrasonic measurements were established for the stone block foundation of the Sungnyemun Gate, a representative stone architectural heritage structure in the Republic of Korea, to enhance the reliability of the weathering evaluation. Furthermore, the extensively used method for evaluating the weathering was improved by proposing weathering standards that accounted for the material characteristics and provenance of the constituent stone materials.

The physical damage on the stone block foundation of the Sungnyemun Gate was mainly attributed to the blistering cracks (crack index 3.71), blistering $(6.8 \%)$, scaling $(7.5 \%)$, and disintegration $(39.2 \%)$. Further, surface contamination and discoloration were primarily caused by the oxidation of the ferruginous mineral and moisture. The continuous attachment of air pollutants, salt crystals, clay minerals, and microorganisms may have increased the discoloration of the stone blocks.

The average difference between the ultrasonic velocities of the original (average $2665 \mathrm{~m} / \mathrm{s}$ ) and new (average $3884 \mathrm{~m} / \mathrm{s}$ ) blocks belonging to the stone block foundation of the Sungnyemun Gate was approximately $1219 \mathrm{~m} / \mathrm{s}$. Additionally, based on the assumption that fresh rock from the provenance site was used during the original construction, the calculation of the rate of weathering as a linear function exhibited that the ultrasonic velocity of pink feldspar granite and leucogranite of the original block decreased annually by approximately 1.8 and $2.4 \mathrm{~m} / \mathrm{s}$, respectively. This rate of weathering could be partly attributed to the intentional damage caused during the Korean War. Thus, it was estimated that the rate of weathering would be lower than these results under natural weathering conditions.

In this study, the relative weathering grade based on the ultrasonic velocity of fresh rocks at the provenance site and absolute weathering grade based on the ultrasonic velocity of a universal hard rock were proposed. The evaluation of the weathering of the stone block foundation of the Sungnyemun Gate exhibited that the original and new blocks exhibited a difference in weathering of approximately two stages. The absolute weathering grade underestimated the overall physical properties and strength compared with the relative weathering grade.

This study makes a significant contribution to improve the reliability of non-destructive testing by proposing a customized model for performing ultrasonic measurements and evaluating the weathering of a stone architectural heritage. In particular, the weathering evaluation method based on the types and origin of the rock can be extensively used to diagnose and monitor similar stone architectural heritage structures.

\begin{abstract}
Author Contributions: Conceptualization, Y.H.J.; methodology, Y.H.J. and C.H.L.; software, Y.H.J.; validation, C.H.L.; formal analysis, Y.H.J.; investigation, Y.H.J.; resources, Y.H.J.; data curation, C.H.L.; writing —original draft preparation, Y.H.J.; writing—review and editing, C.H.L.; visualization, Y.H.J.; supervision, C.H.L.; project administration, C.H.L.; funding acquisition, C.H.L. All authors have read and agreed to the published version of the manuscript.
\end{abstract}

Funding: This research received no external funding.

Institutional Review Board Statement: Not applicable.

Informed Consent Statement: Not applicable.

Data Availability Statement: Not applicable.

Conflicts of Interest: The authors declare no conflict of interest.

\section{References}

1. Fitzner, B.; Heinrichs, K.; La Bouchardiere, D. Weathering damage on Pharaonic sandstone monuments in Luxor-Egypt. Build. Environ. 2003, 38, 1089-1103. [CrossRef]

2. Theodoridou, M.; Török, Á. In situ investigation of stone heritage sites for conservation purposes: A case study of the Székesfehérvár Ruin Garden in Hungary. Prog. Earth Planet. Sci. 2019, 6, 15. [CrossRef] 
3. Vasanelli, E.; Colangiuli, D.; Calia, A.; Sileo, M.; Aiello, M.A. Ultrasonic pulse velocity for the evaluation of physical and mechanical properties of a highly porous building limestone. Ultrasonics 2015, 60, 33-40. [CrossRef] [PubMed]

4. Mesquita, E.; Martini, R.; Alves, A.; Antunes, P.; Varum, H. Non-destructive characterization of ancient clay brick walls by indirect ultrasonic measurements. J. Build. Eng. 2018, 19, 172-180. [CrossRef]

5. Siegesmund, S.; Menningen, J.; Shushakova, V. Marble decay: Towards a measure of marble degradation based on ultrasonic wave velocities and thermal expansion data. Environ. Earth Sci. 2021, 80, 395. [CrossRef]

6. Paoletti, D.; Ambrosini, D.; Sfarra, S.; Bisegna, F. Preventive thermographic diagnosis of historical buildings for consolidation. J Cult. Herit. 2013, 14, 116-121. [CrossRef]

7. Jo, Y.H.; Lee, C.H. Quantitative modeling and mapping of blistering zone of the Magoksa Temple stone pagoda (13th century, Republic of Korea) by graduated heating thermography. Infrared Phys. Technol. 2014, 65, 43-50. [CrossRef]

8. Jo, Y.H.; Lee, C.H.; Yoo, J.H. Application of infrared thermography for conservation treatment on the defect zone of stone monument. Int. J. Appl. Eng. Res. 2014, 9, 8663-8672.

9. Moropoulou, A.; Avdelidis, N.P.; Karoglou, M.; Delegou, E.T.; Alexakis, E.; Keramidas, V. Multispectral applications of infrared thermography in the diagnosis and protection of built cultural heritage. Appl. Sci. 2018, 8, 284. [CrossRef]

10. Labropoulos, K.; Moropoulou, A. Ground penetrating radar investigation of the bell tower of the church of the Holy Sepulchre. Constr. Build. Mater. 2013, 47, 689-700. [CrossRef]

11. Risti'c, A.; Govedarica, M.; Pajewski, L.; Vrtunski, M.; Bugarinović, Ž. Using ground penetrating radar to reveal hidden archaeology: The case study of the Württemberg-Stambol Gate in Belgrade (Serbia). Sensors 2020, 20, 607. [CrossRef] [PubMed]

12. Fitzner, B.; Heinrichs, K.; La Bouchardiere, D. The Bangudae petroglyphs in Ulsan, Korea: Studies on weathering damage and risk prognosis. Environ. Geol. 2004, 46, 504-526. [CrossRef]

13. Gilbert, O.; Mol, L.; Campbell, O.; Blenkinsop, T. Permeability and surface hardness surveying of stone damaged by ballistic impact. Heritage 2019, 2, 1369-1389. [CrossRef]

14. Siedel, H.; Pfefferkorn, S.; Plehwe-Leisen, E.; Leisen, H. Sandstone weathering in tropical climate: Results of low-destructive investigations at the temple of Angkor Wat, Cambodia. Eng. Geol. 2010, 115, 182-192. [CrossRef]

15. Sena da Fonseca, B.; Ferreira Pinto, A.P.; Rodrigues, A.; Piçarra, S.; Fonseca, D.; Montemo, M.F. On the estimation of marbles weathering by thermal action using drilling resistance. J. Build. Eng. 2021, 42, 102494. [CrossRef]

16. Lee, C.H.; Jo, Y.H.; Kim, J. Damage evaluation and conservation treatment of the tenth century Korean rock-carved Buddha statues. Environ. Earth Sci. 2011, 64, 1-14. [CrossRef]

17. Moropoulou, A.; Labropoulos, K.C.; Delegou, E.T.; Karoglou, M.; Bakolas, A. Non-destructive techniques as a tool for the protection of built cultural heritage. Constr. Build. Mater. 2013, 48, 1222-1239. [CrossRef]

18. Wyllie, M.R.J.; Gregory, A.R.; Gardner, L.W. Elastic wave velocities in heterogeneous and porous media. Geophysics 1956, 21, 41-70. [CrossRef]

19. Thill, R.E.; Bur, T.R. An automated ultrasonic pulse measurement system. Geophysics 1969, 34, 101-105. [CrossRef]

20. Mohamad, E.T.; Isa, M.F.M.; Amin, M.F.M.; Komoo, I.; Gofar, N.; Saad, R. Effect of moisture content on the strength of various weathering grades of granite. Electron. J. Geotech. Eng. 2011, 16, 863-886.

21. Kahraman, S. The correlations between the saturated and dry P-wave velocity of rocks. Ultrasonics 2007, 46, 341-348. [CrossRef] [PubMed]

22. Ruedrich, J.; Knell, C.; Enseleit, J.; Rieffel, Y.; Siegesmund, S. Stability assessment of marble statuaries of the Schlossbrücke (Berlin, Germany) based on rock strength measurements and ultrasonic wave velocities. Environ. Earth Sci. 2013, 69, 1451-1469. [CrossRef]

23. Cerrillo, C.; Jiménez, A.; Rufo, M.; Paniagua, J.; Pachón, F.T. New contributions to granite characterization by ultrasonic testing. Ultrasonics 2014, 54, 156-167. [CrossRef] [PubMed]

24. Jo, Y.H.; Lee, C.H. Establishment of ultrasonic measurement method for stone cultural heritage considering water content and anisotropy. J. Conserv. Sci. 2014, 30, 467-480. [CrossRef]

25. Jo, Y.H.; Lee, C.H. A study on selection of ultrasonic transducer and contact material for surface irregularities of stone cultural heritage. J. Conserv. Sci. 2015, 31, 267-278. [CrossRef]

26. Yaman, I.O.; Inci, G.; Yesiller, N.; Aktan, H.M. Ultrasonic pulse velocity in concrete using direct and indirect transmission. ACI Mater. J. 2001, 98, 450-457.

27. Mohamed Sutan, N.; Meganathan, M. A comparison between direct and indirect method of ultrasonic pulse velocity in detecting concrete defects. Russ. J. Nondestr. Test. 2003, 8, 1-9.

28. Turgut, P.; Kucuk, O.F. Comparative relationships of direct, indirect, and semi-direct ultrasonic pulse velocity measurements in concrete. Russ. J. Nondestr. Test. 2006, 42, 745-751. [CrossRef]

29. Lee, C.H.; Jo, Y.H. Correlation and correction factor between direct and indirect methods for the ultrasonic measurement of stone samples. Environ. Earth Sci. 2017, 76, 477. [CrossRef]

30. Tharmaratnam, K.; Tan, B.S. Attenuation of ultrasonic pulse in cement mortar. Cem. Concr. Res. 1990, 20, 335-345. [CrossRef]

31. Lee, Y.; Keehm, Y.; Lee, M.; Han, J.; Kim, M. Assessment and calibration of ultrasonic velocity measurement for estimating the weathering index of stone cultural heritage. J. Korean Earth Sci. Soc. 2012, 33, 126-138. [CrossRef]

32. Iliev, I.G. An attempt to estimate the degree of weathering of intrusive rocks from their physico-mechanical properties. In Proceedings of the First Congress of the International Society of Rock Mechanics, Lisbon, Portugal, 25 September-1 October 1966. 
33. Karpuz, C.; Paşamehmetoğlu, A.G. Field characterization of weathered Ankara andesites. Eng. Geol. 1997, 46, 1-17. [CrossRef]

34. Arikan, F.; Ulusay, R.; Aydin, N. Characterization of weathered acidic volcanic rocks and a weathering classification based on a rating system. Bull. Eng. Geol. Environ. 2007, 66, 415-430. [CrossRef]

35. Fais, S.; Casula, G.; Cuccuru, F.; Ligas, P.; Giovanna Bianchi, M. An innovative methodology for the non-destructive diagnosis of architectural elements of ancient historical buildings. Sci. Rep. 2018, 8, 4334. [CrossRef]

36. Meng, T.; Lu, Y.; Zhao, G.; Yang, C.; Ren, J.; Shi, Y. A synthetic approach to weathering degree classification of stone relics case study of the Yungang Grottoes. Herit. Sci. 2018, 6, 1. [CrossRef]

37. Akoglu, K.G.; Kotoulab, E.; Simon, S. Combined use of ultrasonic pulse velocity (UPV) testing and digital technologies: A model for long-term condition monitoring memorials in historic Grove Street Cemetery, New Haven. J. Cult. Herit. 2020, 41, 84-95. [CrossRef]

38. Jo, Y.H.; Lee, C.H.; Yoo, J.H.; Kang, M.K.; Kim, D.M. Petrological classification and provenance interpretation of the Sungnyemun Stone Block Foundation, Korea. MUNHWAJAE Korean J. Cult. Herit. Stud. 2012, 45, 174-193.

39. Jo, Y.H.; Lee, C.H. Making method of deterioration map and evaluation techniques of surface and three-dimensional deterioration rate for stone cultural heritage. J. Conserv. Sci. 2011, 27, 251-260.

40. Jo, Y.H.; Lee, C.H. Quantitative modeling of blistering zones by active thermography for deterioration evaluation of stone monuments. J. Cult. Herit. 2014, 15, 621-627. [CrossRef]

41. Matula, M.; Dearman, W.R.; Golodkovskaja, G.A.; Pahl, A.; Radbruch-Hall, D.H.; Sanejouand, R. Classification of rocks and soils for engineering geological mapping, Part 1: Rock and soil materials. Bull. Eng. Geol. Environ. 1979, 19, 364-371.

42. Fitzner, B.; Heinrichs, K. Verwitterungszustand und materialeigenschaften der Kalkstein des Naumburger Doms. In Proceedings of the Jb aus dem Forschungsprogramm Steinzerfall-Steinkonservierung, Berlin, Germany, 3-6 June 1990.

43. Köhler, W. Untersuchungen zu verwitterungsvorgangen an Carrara-marmor in Potsdam Sanssouci. In Proceedings of the Berichte zu Forschung und Praxis der Denkmalpflege in Deutschland, Steinschäden-Steinkonservierung 2, Hannover, Germany, 1991.

44. Lee, C.S.; Cho, T. Effects of rock weathering on the degradation of engineering properties. Tunn. Undergr. Space 2005, 15, 411-424.

45. Török, A.; Vásárhelyi, B. The influence of fabric and water content on selected rock mechanical parameters of travertine, examples from Hungary. Eng. Geol. 2010, 115, 237-245. [CrossRef]

46. Irfan, T.Y.; Dearman, W.R. Engineering classification and index properties of a weathered granite. Bull. Int. Assoc. Eng. Geol. 1978, 17, 79-90. [CrossRef]

47. Kiliç, R. Geomechanical properties of the ophiolites (Çankiri/Turkey) and alteration degree of diabase. Bull. Int. Assoc. Eng. Geol. 1995, 51, 63-69. [CrossRef]

48. Fort, R.; Alvarez de Buergo, M.; Perez-Monserrat, E. Nondestructive testing for the assessment of granite decay in heritage structures compared to quarry stone. Int. J. Rock Mech. Min. Sci. 2013, 61, 296-305. [CrossRef]

49. Jo, Y.H.; Lee, C.H. Analysis of ancient document and establishment of petrological database for presumption of stone source area of the Seoul City Wall, Korea. J. Petrol. Soc. Korea 2015, 24, 193-207. [CrossRef]

50. Woo, I.; Park, H.J. Classification of weathering for the granite and granite gneiss in Okcheon Belt-Jecheon.Geumsan.Gimcheon in Korea. Econ. Environ. Geol. 2004, 37, 355-364.

51. Yim, G.J.; Min, K.W.; Kim, J.D. Durability of some domestic building stones. J. Korean Inst. Miner. Energy Res. Eng. 1994, 31, 435-443.

52. Gupta, A.S.; Seshagiri Rao, K. Index properties of weathered rocks: Interrelationships and applicability. Bull. Eng. Geol. Environ. 1998, 57, 161-172. [CrossRef]

53. Dobereiner, L.; Durville, J.; Restituito, J. Weathering of the massiac gneiss (Massif central, France). Bull. Int. Assoc. Eng. Geol. 1993, 47, 79-96. [CrossRef]

54. Yavuz, H.; Altindag, R.; Sarac, S.; Ugur, I.; Sengun, N. Estimating the index properties of deteriorated carbonate rocks due to freeze-thaw and thermal shock weathering. Int. J. Rock Mech. Min. Sci. 2006, 43, 767-775. [CrossRef]

55. Lee, C.H.; Jo, Y.H.; Chun, Y.G. Establishment of ultrasonic measurement and correlations of direct-indirect method for weathering evaluation of stone cultural heritage. J. Conser. Sci. 2009, 25, 233-244.

56. Yang, H.; Duan, H.F.; Zhu, J.B. Ultrasonic P-wave propagation through water-filled rock joint: An experimental investigation. J. Appl. Geophys. 2019, 169, 1-14. [CrossRef] 